\title{
A Review of "Human Security in World Affairs: Problems and Opportunities"
}

\author{
Published: 4 September 2013
}

Keywords: challenges and opportunities for human security; environmental security; human security

\author{
Human Security in World Affairs: Problems \\ and Opportunities \\ Alexander K. Lautensach, Sabina W. Lautensach \\ (eds.) \\ Caesarpress: 2013 \\ 504 pp.; ISBN: 978-3-902890-00-9
}

While security of our hominid encampments and settlements must have been at or near the top of our species priorities since our evolution some several hundred thousand years ago, awareness of the magnitude of our alterations, interactions and impacts on our world is a very recent event. Even more recent is our collective and growing angst over how our species is to secure some sort of permanence on a planet that is ultimately governed by natural forces and is forever changing.

As an environmental biologist, and one who has been particularly interested and concerned by the rising levels of greenhouse gases and their attendant effects on global changes, and as an educator, I am delighted to see a book such as this. With an ambitious mandate, to probe all major facets of modern human security, Alexander and Sabina Lautensach have brought together their vision and ideas, and along with those of a host of co-authors from around the world, have edited a book that is both comprehensive in scope and understandable for a broad audience. The thoughtful and succinct preface and introduction sections written by the editors are well worth a careful read prior to engaging with the chapters. These are well written and thought-provoking. The short section on environmental security in the introduction will likely end up as required reading for one or more of my senior undergraduate or graduate classes relating to the environment. It is concise, but also is successful in bridging social and natural sciences-of great importance if we are to make collaborative progress on this issue. In addition, as in all other chapters, learning outcomes, suggested readings and glossaries provide a solid launch pad for further examination.

Chapters 1 and 2 complete the introduction for me. Chapter 1 lays out the history of modern 'human security' from the term's inception in 1990s, to its disaggregation into seven core areas, namely economic, food, health, environmental, personal, community, and political, in the 1995 UN World Summit for Social Development report. While the book is not organized along these seven core areas, subsequent chapters address all of these themes. Listings of foundational documents and other resources appearing in this chapter should be useful for professor and student alike. Chapter 2 answers the all-important question: 'why should we care?'. The linkages between environmental degradation, fossil fuel combustion, and our human population increases are highlighted in the four major findings of the Millenium Ecosystem Assessment.

Chapters 3 through 19 delve into specific aspects of human security that, while not designed to be sequential, are reasonably logical in their flow. For example, Chapter 3 begins with an examination of the influence of perspective on human security, while 
Chapter 4 provides a very useful overview of all perceived threats to human security, but with a decidedly strong emphasis on violent conflict. Examinations of international law (humanitarian and criminal) (Chapter 5), those living outside of the 'state' system (Chapter 6) or under hybrid governance systems (Chapter 7) and their impacts on human security are considered in order-making a logical grouping of topics. The chapter on globalization (Chapter 8) might have been introduced earlier, but is a necessary one for this book. Environmental decay is addressed in chapters 9 and 10, providing a thoughtful consideration of the cognitive underpinnings of such things as greed and overconsumption which lead to resource scarcity and anthropogenic degradation of the environment. Ronnie Hawkins (Chapter 11) deconstructs the human war on nature-which she rightfully likens to war on ourselves. Her optimism for the future provides some keys to positive ways forward. The chapter on transnational crime (Chapter 11) might have been better placed next to Chapter 5 , but clearly portrays the significance of transnational versus international crime. The next 3 chapters address the importance of local governance (Chapter 13), adequate human rights (Chapter 14) and environmentally conscious governance (Chapter 15). The last chapter resonated with me. Many countries such as my own are founded on 'good governance', yet it seems to me that our governments of today are increasingly mired in politics of yesteryear-unable to meet the definition of good governance today, i.e. giving proper regard to environmental security. The next chapter (16) addresses health security for humans, but as an environmental biologist, I would have liked to have seen discussion of larger questions, to some extent addressed in other chapters. For example, the authors do give a nod to preventative medicine and adequate nutrition, but fail to address the larger problem of the long-term health of our species in the face of things like overpopulation-itself a product of human healthcare improvements. Chapter 17 makes a strong case for enhancing human security through the advancement and enforcement of international law. Chapter 18 provides a very concise and understandable treatment of peace building, and convincing this reader that it is indeed a necessary condition for human security. Of greater interest to me was Chapter 19 dealing with global environmental governance. While the chapter lacked specifics and global precedents and examples, it did provide an overview of GEG.

The capstone and final chapter of this book (Chapter 20), authored again by the editors, attempts to weave the disparate threads of the intervening chapters into a cohesive fabric of the overall human security challenge and opportunity. I'm not sure they truly succeed-the problem of our future security, perhaps the problem of our species, is as vast and deep as it is complex. Caught up in religious, political, corporate, and economic paradigms or orthodoxies that now appear ill-suited for our long-term survival, it is clear that some fundamental shifts will need to be made. Opportunities exist, although simultaneously meeting the needs of all forms of human security is clearly going to be a tall order. Yet, the editors provide us with some reasonable assumptions and places to begin. I could not agree more that our most pressing and overarching security challenge is our environment, and in particular, our perilous state of environmental overshoot. I also agree that the only rational way forward to solve this overshoot is by decreasing our population growth and size and the inequities of the environmental impact that result. As an educator, I am also in agreement that educational practices and our definitions of modernity and progress need shifting to reflect our current situation. Finally, while I think many could agree with the conclusion that national/local rather than global governance offers the more promising avenue for security policy remediation, I wished that more mention was made of the local levels. In my experience with environmental security at least, local level experimentation with and adaptation of new approaches are often far ahead of that of their nation state.

Ultimately, this book succeeds on so many levels, and if the chapters are considered carefully, a picture should emerge without prompting. What I take great heart in is that scholars the world over are recognizing our species' increasingly perilous situation, and are working so diligently to imagine and create a secure future for our species. We should all be grateful for these efforts, but more importantly, we should take heed and take action, contributing to what is arguably the most important dialogue and undertaking of our time.

\section{Arthur L. Fredeen}

Natural Resources and Environmental Studies Institute, University of Northern British Columbia, 3333 University Way, Prince George, BC, V2N 4Z9, Canada; E-Mail: arthur.fredeen@unbc.ca 